\title{
Determinants of child labour in Crop Production (A Case Study of
}

\author{
Anambra State of Nigeria). \\ Determinantes del trabajo infantil en la producción de cultivos \\ (Un estudio de caso del estado de Anambra de Nigeria).
}

Ume Smiles, Ifeanyichukwu ${ }^{1}$, Ezeano, Caleb Ike ${ }^{2}$ and Anthony Kingsley Ogbonna Nnadozie ${ }^{3}$

1- Department of Agricultural Extension and Management, Federal College of Agriculture,

Ishiagu, Ebonyi State. Nigeria. Author for correspondence, email: umesmilesi@gmail.com

2- Department of Agricultural Economics and Extension, Nnamdi Azikiwe University, Awka, Anambra State, Nigeria.

3- Department of Marketing, Federal College of Agriculture, Ishiagu, Ebonyi State. Nigeria.

\section{ABSTRACT}

Determinants of child Labour use among rural household crop farmers in Anambra State of Nigeria were studied. A multistage random sampling technique was used to select one hundred (100) respondents for the detailed study. A structured questionnaire was used to elicit information from the respondents for the study. Percentage response was used to capture objective $\mathrm{i}$ and iii. Objective ii was capture using Probit model analysis. The result showed that majority of the respondents were married, youthful, had moderate household size, educated and highly experienced in farming. The determinant factors to the use of child labour among rural household were relationship between the child and household heads, access to credit and educational level. The major operations accomplished by the children in the study area were bird scaring, fertilizer application and planting. The child right act should be enforced by appropriate government agencies and the offenders brought to book, free education to all children and social mobilization on change of attitude to use of child labour were recommended. 
Keywords: Determinants, Child Labour, Crop Production, Anambra State, Nigeria

\section{RESUMEN}

Los determinantes del uso de mano de obra infantil entre los agricultores de cultivos rurales en el estado de Anambra en Nigeria. Se utilizó una técnica de muestreo aleatorio de múltiples etapas para seleccionar cien (100) encuestados para el estudio detallado. Se utilizó un cuestionario estructurado para obtener información de los encuestados para el estudio. El porcentaje de respuesta se utilizó para capturar el objetivo iy iii. El objetivo ii fue la captura utilizando el análisis del modelo Probit. El resultado mostró que la mayoría de los encuestados estaban casados, eran jóvenes, tenían un tamaño familiar moderado, educados y tenían mucha experiencia en la agricultura. Los factores determinantes del uso del trabajo infantil en el hogar rural fueron la relación entre el niño y los jefes de hogar, el acceso al crédito y el nivel educativo. Las principales operaciones llevadas a cabo por los niños en el área de estudio fueron el espantapájaros, la aplicación de fertilizantes y la siembra. El acto correcto del niño debe ser aplicado por las agencias gubernamentales apropiadas y se recomienda a los delincuentes que traigan libros, educación gratuita para todos los niños y se recomienda la movilización social sobre el cambio de actitud hacia el uso del trabajo infantil.

Palabras clave: Determinantes, trabajo infantil, producción de cultivos, estado de Anambra, Nigeria

\section{INTRODUCTION}

Child labour is a threat in the path of children's and society's attainment of sustainable developments. This is because discovering and learning to one's fullest potential during childhood determines what opportunities will be available not only to the individual but also to the next generations (International Labour Organisation,(ILO) 2011). Child labor is that work that deprives children of their childhood, their potential and dignity, and that is harmful to physical-mental development (Basu and Tzannatos, 2003). It refers to work that is mentally, physically, socially or morally dangerous and harmful to children, and interferes Sustainability, Agri, Food and Environmental Research, with their schooling by depriving them of the opportunity to attend school, obliging them to leave school prematurely or 
requiring them to attempt to combine school attendance with excessively long and heavy work (UNESCO, 2006). Child labor violates human rights, and is in contravention of the International Labor Organization (Article 32, Convention Rights of the Child).

Although, the statistical figures about child workers in the world have variation because of the differences in defining categories of age group and engagement of children in formal and informal sectors. Nevertheless, in 2008, 60\% of the 215 million boys and girls were estimated to be laborers worldwide. Incidentally, $96 \%$ of the child workers are in the developing countries of Africa, Asia and South America (ILO, 2015). With respect to the child workers between the ages of 5 and 14, Asia makes up $61 \%$ of child workers in developing countries, while Africa had 32\% and Latin America 7\%. Further, while Asia has the highest number of child workers, Africa has the highest prevalence of child labor (40\%) (United Nation International Children Emergency Fund(UNICEF),2007). The child labour in African is orchestrated, sustained and reinforced by extreme wide spread poverty due to loss of livelihoods as a result of economic recession, sudden poverty as a result of disaster or conflict, the poverty of low-wage workers, and the alter destitution of people who fall outside family support systems, social institutions and safety nets (Tiwari, 2005, Burra, 2009). The other reasons for use of child labour in rural communities are limited access to education, inadequate agricultural technology and access to adult labour, high hazards and risks, and traditional attitudes towards children's participation in agricultural activities (Okpukpura, et al. 2006; UNICEF, 2007), seasonal work, migratory lifestyles, low levels of awareness, low unionization, lack of decent work for adults and lack of enforcement of labour laws are the main causes of the prevalence of child labour in rural economies (Enagbase, 2006, Webbink, et al.., 2011). Child labour is found more in informal sector of the economy, particularly agricultural sector in most rural areas of the developing nations, where every efforts to checkmate is increasingly difficult (Bhalotra, 2003). This scenario as reported by Burra, (2009) could be linked to the fact that rural child labour is often invisible as it is hidden in remote farms, in mountain areas herding livestock, in domestic work in private homes, in informal rural enterprises and markets and in forest exploitations. Others are limited coverage of agriculture and family undertakings in national labour legislations, limited unionization, fragmentation of the labour force, majority of child labourers working as unpaid family labour without formal contracts, continuity between rural household and the workplace, and traditions of children participating in agricultural activities from young age (Bhalotra, 2003; Basu, Das and Dutta, (2007).

These children in the course of accomplishing the crop production activities are often 
exposed to risks, which include exposure to chemicals, organic dusts and biological hazards (Yadav and Gowri - Sengupta, 2009). In addition, they are in contact with psycho-social hazards, abuse and sexually transmitted diseases, increased by isolation, poverty (Bhalotra, and Heady,(2000); Beegle, Dehejia and Gatti,(2004)), long periods of stooping and repetitive movements, carrying heavy loads over long distances, work in extreme temperatures and without access to safe water (Buchmann, 2000, Das and Mukherjee, 2007).

It is paramount to state that efforts of governments and donor organizations to curtail child labour have not yielded the desired dividends, as over 200 million children are still found on paid working places worldwide (Ali, et al.; 2004; ILO 2010). To improve this situation, it is of important to be fully equipped with factors that could influence the decisions of parents (or other caretakers) of engaging their wards into paid employment as well as the push or pull factors of children into the labor market. For this study, efforts is geared towards the influence of the parents or other caretakers as against in other studies that dwelled on all levels (household, national and region) (Khan, et al.;2007, Fekadu, el al;2009).This is because the major decision makers regarding child's work or education are centred at on the household head, but other family members may also contribute. The decision of household head has four possible outcomes; the child can be in school, it can be engaged in paid work, it can be both in school and engaged in paid work and it can be neither in school nor engaged in paid work (Khan, et al. 2007, Busa, et al. 2007). Furthermore, when modeling the determinants of child labour supply, the household is taken as the unit of analysis. In addition, several studies (Ali, et al. 2004; Bura, 2009; Sanusi and Akinniram, 2010) reported that household income is the major determinant in the decision of household head to child labour supply. Nevertheless, prohibiting child labour use generally among the institutions concerned, will entail not just making the laws but greater commitments by implementing agencies as this will be met with stiff opposition considering the gains accruing from the use of the labour (International Labour Organisation (ILO); 2005; Manacorda and Rosati, 2007).However, eliminating child labour entails inculcating programmes that are capable of increasing awareness on evils of child labour, making education affordable across all levels and enforcement of anti-child labor laws. Furthermore, such programme be able to address the problems of the four pillars of decent work, which are provision of quality jobs, which provide income to cover at least basic needs, ensure minimum income security to reduce households' need, provision of old age pension scheme and provision of basic health facilities (UNICEF, 2007, ILO, 2015). 
In this study, an attempt was made to examine the socioeconomic determinants of child labour and the types of crop farming activities engaged by the children in Nigeria using Abia State as a case study. In the absence of an easily discernable national frame work in the protecting the right of child especially in the rural areas and given the ever growing global legislations and resolutions against child labour, the empirical determinants of child labour would help in the formulation of appropriate child welfare for the nation.

\section{MATERIALS AND METHODS}

Anambra State is the study area and located between latitude $5038 \mathrm{~N}$ and $6047 \mathrm{E}$ and longitude 6036 ' $\mathrm{N}$ and 7021 'E. The state is bounded in the east by Enugu State, in the West by Delta State, in the South by Imo State and in the North by Kogi State. Anambra State has Awka as capital with population figure of 4.184 million people (NPC, 2006). Among the arable crops grown in the state are cassava, yam, rice and maize, the cash crop grown including cocoa, kola, oil palm and cashew. The livestock reared include goat, pig, sheep, poultry and fishery. Apart from agriculture, other economic activities engaged by the people include barging, hair dressing salon, vulcanizing, petty trading and others. A multistage random sampling technique was used to select Local Government Area (LGA), towns, villages and respondents. First, ten LGAs were randomly selected out of seventeen. Second, from each of the selected LGAs, five (5) towns were randomly selected, giving a total of fifty (50). Thirdly, from the selected towns, twenty (20) villages were randomly selected. A total of one hundred (100) villages were randomly selected. Finally, a farming household head that engaged in child labour were purposively selected from each of the villages selected. This brought to a total of one hundred respondents for detailed study.

The information that was used in this study was derived from two main sources: primary and secondary sources. The primary data were obtained through use of structured questionnaires, while secondary sources were elicited from textbooks, seminars, published and unpublished documents, the internet, journal and other periodicals.

Probit analysis was used to analyze the study and specified as:

$Y=B^{\beta} 0+B 1^{\beta} 1 \times 1+B 2 \beta 2 \times 2+B 3^{\beta} 3 \times 3+B 4 \beta 4 \times 4+B 5^{\beta} 5 \times 5+B 6^{\beta} 6 \times 6+B 7 \beta 7 \times 7+u \ldots .(1)$

Where: $\mathrm{Y}$ is the dummy variable which takes the value of unity; if a child participated in any farm activity and 0 , if otherwise. 
$\mathrm{X} 1=$ Age of household head in years, $\mathrm{X} 2=$ Gender $($ Boy, $=1$, girl; 0), X3 = relationship between the child and household heads, $X 4=$ Poverty level of household head in Naira, X5 = Educational level of household head, $X 6=$ Years of family experience of Household head, $\mathrm{X} 6=$ Access to credit (Access, 1 and 0 ; if no access. $u=$ error term; $B=$ vector of unknown parameters to be estimated

\section{RESULTS AND DISCUSSION}

The average statistics of the sampled children are presented in Table 1. A typical child is 15 years old with 12.45 years of education and put in to agricultural activities to the tune of N12,987. His household has a size of 8 persons with an income of N346, 890.5 and the head is 54 years with education of 11.32 years. Furthermore, out of 60 children sampled for detailed study, 76 participated in agricultural activities representing 76\%, while 24 children representing $24 \%$ did not. In addition, the male children in the sample were 68 representing $68 \%$ of the sample size, while females were 23 in number representing $2338 \%$. The coefficient of age was significant and negatively related to child labour use in crop production in line with a priori knowledge as indicated in Table 2 . This implies that as the age of the household advances, the more likelihood of using children in farming, since at old age, most household heads' ability to do manual work decreases (Iheke, 2010). The coefficient for gender was statistically significant and negative in conformity with apriori expectation and to the report from Lopez - Calva, (2002); Yakilde and Atala, (2005) and Tiwari, (2005). The negative value of the gender coefficient indicates that female headed households dominated the study and more likely to use children to accomplish some of the crop production farming activities more than male headed household counterparts.

The coefficient of the relationship between child and household heads was significant and had direct relation with the child labour use in crop production in the study area. As paid child labor is often used to make ends meet, it is expected that household heads that foster children are more engaged in this kind of work. Household heads might prefer their own children to receive a better education since children are a means of old age social security than foster children (Beegle, et al. 2004; Maitra, et al. 2006). However, because they might take over or inherit the enterprise, work experience on the family farm might also be important for biological children (Nkamlau and Kielland, 2006; Ume, et al. 2012). 
Sustainability, Agri, Food and Environmental Research, (ISSN: 0719-3726), 6(1), 2018: 45-57

http://dx.doi.org/10.7770/safer-V6N1-art1354

Table 1. Average statistics for Sampled Children

\begin{tabular}{ll}
\hline Variable & Mean \\
\hline Age of the child in Years & 14.82 \\
Education of the Child (Years) & 12.45 \\
Household Size(N) & 7.84 \\
Contribution of the child to the family in monetary terms & 12,987 \\
Age of household head in Years & 54,32 \\
Income of the household head (N) & $346,890.5$ \\
Education of child's household head & 11.32 \\
Sex of the child; Male or (female) & $68(32)$ \\
Participation in farming Yes or (No) & $76(24)$ \\
\hline
\end{tabular}

Source: Field Survey; 2016

N/B. $N=$ is the Nigeria national currency, with Dollar exchange rate of 365 per dollar

Table 2. Determinants of Child Labour Participation Using Probit model Analysis

\begin{tabular}{|c|c|c|c|}
\hline Variable & Coefficient & Standard Error & $\mathrm{t}$ - value \\
\hline Interception & 0.728 & 0.223 & $3.262 * * *$ \\
\hline Age & -0.1501 & 0.05249 & $-2.8676 * *$ \\
\hline Gender & -0.408 & 0.285 & $-1.720 *$ \\
\hline Relationship between child and household heads & 0.911 & 0.161 & $5.658 * * *$ \\
\hline Access to Credit & 0.700 & 0.203 & $3.370 * * *$ \\
\hline Educational Level & 3.882 & $0.7 .8542 * * *$ & $7.842 * * *$ \\
\hline
\end{tabular}

No of observation $=100$

LR Chi $=340$

Log likelihood $=335.0605$

Pro $>$ chiz $=0.7577$

Source: Field Survey; 2016

The coefficient of access to credit was positive signed and significant at $1 \%$ probability level. 
Studies inform that credit-constrained household head could cause use of child labour. For example, if household head expect family income to be rising over time, then they may find it optimal to borrow against the future so as to smooth consumption across time (Lieten, 2003, Yikade and Atala, 2010, Ume, et al. 2012). This study is contrary to a priori expectation and the observation made by Webbinck, et al. (2011), who reported that if household head do not have access to credit markets, then they have to rely on internal assets by putting their children to work rather than investing in human capital that will make their children more productive in the future. The coefficient of level of education was positive and significant at $1 \%$ probability level. Empirical evidences show that education of the parents affect child labour decision positively (Ray, 2006, Mendonca, 2007, Self and Grabswski, 2009). They opined that the educational status of the father and mother have significant impacts on the sons and daughters respectively in participation in the labour markets. This finding is in consonance with Basu and Tzannatos, (2003), who reported that education is a vehicle through which people are empowered to improve their quality of life and by which they are protected from all forms of exploitation such child labour. To eliminate child labour, it is imperative that we establish free, compulsory, equal and quality education for all children no matter the race, gender religion and socioeconomic status. Table 3 shows the crop production activities engaged by the children in the study area. The major crops considered in the study were cassava, rice, cocoyam and maize. Among items considered, bird scaring in rice farm encountered the highest number of use of child labour as reported by $83.3 \%$ of the respondents Bird scaring in rice paddy is one of the least tedious crop production operations but requires long hours of working with meagre wage, of which only children can accept. This is followed by fertilizer application, reported by $66.7 \%$ of the sampled farmers. Fertilizer particularly inorganic application is less tedious especially where broadcasting method as use in rice paddy is applied. This finding concurred to Ume and Okoye, (2006), who opined that children are often used to accomplish light jobs in farming, although, less efficient in the job. The least of the farming activities carried by the children was tillage operation and represented by $30 \%$ of the respondents. Tillage system is a tedious operation and as result needed the services of able bodied and energetic individuals to accomplish (Ume, 2006). The determinants of child labour were access to credit, educational level and relationship between household heads and the child. The major crop production operations activities in which children were used in the study area were bird scaring, fertilizer application and planting. 
Table 3. Crop Production Activities Engaged by Children

\begin{tabular}{lll}
\hline Variables & Frequency & Percentage \\
\hline Clearing & 45 & 43.3 \\
Tillage & 30 & 25 \\
Ridging/ Mounding & 45 & 43.3 \\
Planting & 68 & 56.7 \\
Weeding & 70 & $58 . .4$ \\
Fertilizer Application & 80 & 66.7 \\
Bird Scaring & 100 & 83.3 \\
Harvesting & 35 & 29.2 \\
Transportation & 68 & 56.7 \\
Nursery Preparation & 40 & 33.3 \\
\hline
\end{tabular}

Source: Field Survey: 2016

Based on the results, the following recommendations were proffered: (1) Government should put in place educational policies that could facilitate children attending school. These policies include free education that is not limited because of the need to purchase supplies and uniforms, unbiased education where the rights of girls and minorities are protected, and supplemental meal programs to encourage poor children to attend school and enhance their academic performance when they attend. (2) Social mobilization through campaigns to provide information, raise awareness and change attitude of people towards child labour through exposing the occupational hazards involved. (3) Advocacy for the right of child and enacting laws and policies aimed at eliminating all the forms of child labour. The advocacy should monitor the progress of the implementations and enforcement of the laws. (4) Government should make policies to enhance access of the household heads to credit facilities through commercial banks and microfinance banks in order to boost their income. This credit could be used to hire labour instead of using the labour of under aged. 


\section{REFERENCES}

Ali, M. S, Shahab, H, Ushijima H \& De Muynck A, 2004. Street children in Pakistan: A situational analysis of social conditions and nutritional status. Soc Sci Med. 59:17071719

Aliyu, A. 2002. Poverty in Nigeria: factual dimension and existing policy responses. A paper presented at the all stakeholders National workshop in Nigeria. Poverty Reduction, strategy paper and related activities Abuja Nigeria. 2pp.

Basu, K. S, Das. \& Dutta, B,2007. Child labor and household wealth: Theory and empirical evidence of an inverted U. IZA discussion paper no. 2736.

Basu, K. Z. \& Tzannatos Z. 2003. The Global Child Labor Problem: What Do We Know and What Can We Do? World Bank Econ Rev.17: 147-73.

Beegle, K.R, Dehejia \& Gatti R,2004. Why should we care about child labor? The education, labor market, and health consequences of child labor. Working paper 10980. NBER working paper series.P16

Bhalotra, S. 2003. Child labour in Asia and Africa. Background research paper for the EFA monitoring report.P18

Bhalotra, S. \& Heady C, 2000. Child farm labor: Theory and evidence. SticerdDevelopment Economics papers. P24.

Burra, N. 2009. "Child labour in rural areas with a special focus on migration, agriculture, mining and brick kilns" National Commission for Protection of Child Rights. retrieved on 2009 Oct 19]. www.ncpcr.gov.in/report

Dowvana, D. 2004. Constraints limiting girls quality of life: Improving the quality of life of girls. United Nations Children Fund Programme Publication. New York NV 10017 U.S.A. P21

Dercon. S. 2006 Rural Poverty old challenges in new context Global poverty research group (GPRP). WPS. 072 University of Oxford, June 2006.P56.

Enaghase, S. 2006: Child labour on the increase in Africa labour and employment Daily Independent June 5. P 17.

Fekadu, D., Alem A, \& Hägglöf B., 2006. The prevalence of mental health problems in 
Ethiopian child labourers. J Child Psychological Psychiatry. 47: 954-959

Hills M.E. \& Kings. E, 2009. Women's Education in Developing Countries. Barriers, Benefit and Baltimore, Maryland John Hoplains University Press. P 31

Iheke, R.O. 2010. Market access, income diversification and welfare status of rural farm households in Abia State. Nigeria. Nigeria Agricultural Journal 4(2): 13-18

International Fund for Agricultural Development (IFAD), 2001. Rural Poverty Report, 2001. The challenges of Ending Rural Poverty. Oxford University Press. P 49

Laraqui, C, Caubet H.A, Laraqui O, Belamallem I, Harourate K, \& Curtes J.P., 2013. Child labour in the artisan sector of Morocco: Determinants and health effects. Sante Publique.12: $31-38$

Lieten, G.K. 2003. The causes for child labour in India: The poverty analysis. Indian J. of Labour Econ. 45: 451-464 International Labour Organization (ILO), 2011.Good practice guide for addressing child labour in fisheries and aquaculture: Policy and practice preliminary version international labour organization. P201

International Labour Organization (ILO), 2005. Every child courts: New global estimates on child labour general. P12.

Lóez-Calva, L.F, 2002. A social stigma model of child labor. Estud. Econ. 17: 193-217.

Maitra, P. Panda B, \& Sarangi S, 2006. Idle child: The household's buffer. Working paper on International Conference on child labour held at Darkar. Senegal

Manacorda, M, \& Rosati, F. C. 2007. Local labor demand and child labor. Conference paper for IZA conference held at Paris, France. P41

Nkamleu, G.B, Kielland A, 2006. Modeling farmer's decisions on child labor and schooling in the cocoa sector: A multinomial logit analysis in Côte d'Ivoire. Agr. Econ. 35: 319333.

Mendonca, I. 2007 "Child Labour in India promises to keep" FRCH New Sktte VI (5) September-October, Pp. 15-18.

National population Commission Report (NPC) 2000 population census of the Federal Republic of Nigeria Abuja. Nigeria. 13p 
Okpukpara, CB, Chine P.U., Ugwu F.N, \& Chukwuonye N, 2006. Child Labour and Poverty in Nigeria. Paper presented at poverty phase Dissemination workshop, Addis Ababa, Ethiopia. 12th -13th October. P 21.

Ray, R. 2008. How Child Labour and child schooling interact with Adult Labour University of Tasmania working paper, Pp. 14 - 17.

Tiger, C. \& Little F, 2007. People and the planets. Spec. Rep. Educ. Girls, 2: 14-14.

Tiwari, R.R. 2005. Child labour in footwear Industry: Possible occupational health hazards. Indian J. Occ. Env. Med, 9: 7-9.

Shaibu, B.A. Aliyu C, \& Bakshi J.S. 2011.Nigeria Agricultural Research Strategy Plan: 19962010. Federal Ministry of Agriculture and Natural Resources Abuja. Federal Capital Territory, Nigeria. P45

Sanusi, W.A.T, \& Akinnniram N, 2010. Effect of Households Poverty level on Child Labour participation among households in Nigeria. Ph.D thesis of Department of Agricultural Economics and Extension, Ladoke Akintola University of Science and Technology, Ogbomoso. Oyo State, Nigeria. Pp. 23 - 27.

Self, S., \& Grabowski R, 2009. Agricultural technology and child labor: Evidence from India. Agricult. Econ, 40: 67-78.

Ume, I. 2007 Government legislations and barriers to Child Labour in Nigeria. Daily Independent March, 4, Pp. 13 - 14.

Ume S.I., \& Okoye, F. U, 2007. Child Labour in rice production. Case study of Anambra agricultural zone of Anambra State, Nigeria. Ebonyi State Univ. J. Arts and Social Sci. Educ., 1: 333-339.

United Nation Children Emergency Fund (UNICEF), 2006. Guide to the Convention on the Rights of the Child. 2006. [Last accessed on 2006]. Available from: http://www.unicef.org/crc/ United Nations Educational, Scientific and Cultural Organization (UNESCO) 2006. Institute for statistics (CD-Rom), Education for All; Year 2000 Assessment A decade of education, country report, Nigeria (Paris, 2000). Pp; 23 $-27$

United Nations Development Programme (UNDP), 2005. Human Development Report Retired September 13, 2005 from http:www-w.ndp.org.hdv2005. 
Sustainability, Agri, Food and Environmental Research, (ISSN: 0719-3726), 6(1), 2018: 45-57

http://dx.doi.org/10.7770/safer-V6N1-art1354

Webbink, E.J, Smits, J. \& De Jong E, 2011. Hidden child labor: Determinants of housework and family business work in 16 developing countries. World Development. doi:10.1016/j.worlddev.2011.07.005

World Bank, 2006 'Nigeria: Poverty in the midst of plenty. The Challenges of growth with inclusion". A World Bank Poverty Assessment Handbook P. 91. Population and Human Resource Division paper; No 14733-UNI, Washington, D.C. the World Bank.

Yadav, S.K. \& Gowri S.G, 2009. Environmental and occupational health problems of child labour: Some Issues and Challenges for Future. J Hum Ecol. 28:143-8.

Yikade, G, \& Atala K.T, 2005. Analysis of Girls Child Labour participation in Rice Production in middle belt in Nigeria. Paper presented at poverty alleviation workshop at Benue State University Makurdi, Nigeria. pp. 14.

Received: $08^{\text {th }}$ January 2018

Accepted: $27^{\text {th }}$ February 2018 